\title{
Perancangan Aplikasi Penentu Faktor Risiko Diabetes Melitus Tipe 2 Secara Dini Berbasis Web
}

\author{
Feby Erawantini ${ }^{1}$, Sustin Farlinda ${ }^{1}$, Retno Ayu Wulandari ${ }^{1}$ \\ ${ }^{1}$ Jurusan Kesehatan, Politeknik Negeri Jember, Jln Mastrip Kotak Pos 164 Jember \\ feby_era@yahoo.co.id"
}

\begin{abstract}
Based on the results of research and data collection techniques of interview, observation, brainstorming about the symptoms and risk of $2^{\text {nd }}$ type diabetes mellitus with an expert, it can be designed a tool for Bondowosocommunity who can be predicted the risk of $2^{\text {nd }}$ type diabetes mellitus quickly and accurately. This system is called as the determinant application of riskdiabetes mellitus factors early in the Web-based Bondowoso district. This application uses web-based programming. Every year, diabetes mellitus patients in Indonesia is growing up. It coused by the ungood lifestyle of people who are following western style. Where it happenedin Bondowoso district, where during 3 years before the number of $2^{\text {nd }}$ type diabetes mellitus patientsis getting increased. Diabetes mellitus or diabetes is a chronic disease caused by reduced production of insulin from pankrease or the insulin produced is not effective in reducing blood sugar levels. From all types of diabetes incidence that most of the cases of $2^{\text {nd }}$ type diabetes caused by obesity as well as the major factors of unhealthy lifestyle. Disease with a high prevalence can not be cured completel but, it can be prevented becoming chronic by controled. The aim of this researchis to Design Applications of $2^{\text {nd }}$ type Diabetes Mellitus Disease DeterminantsThe Risk Factors Early by Web Based on Bondowoso district. With this application, the expected number of people with $2^{\text {nd }}$ type diabetes mellitus in the regency can be detected early in order not become the chronic stage.
\end{abstract}

Keywords: Aplication, $2^{\text {nd }}$ Type diabetes mellitus, Web

\section{Pendahuluan}

Jumlah penderita diabetes melitus di dunia menurut WDD(World Diabetes Day) 2014 terdapat 382 juta orang yang menderita diabetes melitus tahun 2013, sedangkan negara Indonesia menduduki peringkat ke 5 penderita diabetes melitus terbanyak di dunia (Depkes RI, 2008). Jumlah populasi penderita berdasarkan data Riset

Kesehatan Dasar (RisKesDas) tahun 2013 di Indonesia terdapat 10 juta orang penderita Diabetes, dan 17,9 juta orang yang berisiko menderita penyakit ini. Sementara Provinsi Jawa Timur menempati urutan no 9, jumlah penderita diabetes di Indonesia 5,7 persen penderita Diabetes mayoritas di derita oleh perempuan. Data yang didapatkan dari Dinas Kesehatan Provinsi Jawa Timur (2012) 10 besar penyakit terbanyak pada pasien rawat jalan di rumah sakit tipe B Diabetes Melitus merupakan penyakit terbanyak nomor dua setelah hipertensi yakni sebanyak 102.399 kasus.

Menurut WHO (1999) Diabetes adalah suatu penyakit kronis yang terjadi apabila pankreas tidak memproduksi hormon insulin dalam jumlah yang cukup atau tubuh yang tidak efektif menggunakan hormon insulin yang sudah dihasilkan. Dampak yang ditimbulkan oleh DM tipe 2 tidak hanya penyakit yang diderita seumur hidup tetapi juga dapat menyebabkan kematian, memerlukan biaya besar untuk perawatan kesehatan penderita DM, oleh sebab itu sangat dipelukan program pengendalian untuk pasien DM tipe 2. Kesadaran pasien atau penderita masih cukup minim untuk berobat ke tempat pelayanan kesehatan. Berdasarkan studi pendahuluan yang peneliti lakukan dengan pihak P2-PL.

Menurut data dari Dinas Kesehatan Kabupaten Bondowoso prevalensi kasus Diabetes melitus tipe 2 di Kabupaten Bondowoso cendurung meningkat pada 3 tahun terakhir ini. Berdasarkan juknis pengukuran risiko penyakit diabetes melitus tipe 2 tahun 2008 Program pengendalian jumlah kasus Diabetes Melitus Tipe 2 ini dapat dilakukan dengan cara mendeteksi secara dini risiko penyakit Diabetes Melitus Tipe 2. 
Tabel 1. Jumlah penderita DM tipe 2 di kabupaten Bondowoso

\begin{tabular}{cc}
\hline Tahun & Jumlah penderita DM tipe 2 \\
\hline 2013 & 1195 \\
2014 & 1560 \\
2015 & 1834 \\
\hline
\end{tabular}

Sumber : Laporan Jumlah Penderita Diabetes Melitus Tipe 2 Di Dinas Kesehatan Kabupaten Bondowoso (2013 - 2015)

Berdasarkan Tabel 1.1 jumlah penderita DM tipe 2 di kabupaten Bondowoso pada tahun 2014 naik menjadi 1560 disusul untuk tahun 2015 menjadi 1834. Kenaikan jumlah penderita setiap tahun. Dinas Kesehatan Kabupaten Bondowoso memiliki Program dari Depkes RI untuk mengurangi jumlah penderita Diabetes Melitus Tipe 2 dengan cara mendeteksi secara dini penyakit Diabetes Melitus Tipe 2 ini. Adanya aplikasi untuk pendeteksian secara dini terhadap masyarakat diharapkan jumlah penderita Diabetes Melitus berkurang untuk setiap tahunnya khususnya di kabupaten Bondowoso.

Seiring dengan jumlah penderita DM tipe 2 pada Tabel 1.1 jumlah penderita DM tipe 2 di kabupaten Bondowoso setiap tahunnya meningkat dan terlambatnya seseorang mengetahui secara dini tentang diabetes melitus tipe 2 kemampuan teknologi informasi dalam bidang kesehatan dapat dimanfaatkan untuk proses menangani masalah ini dengan cara penentuan secara dini risiko penyakit DM tipe 2, $\quad$ Santoso dkk ( 2012) dalam penelitiannya manyatakan bahwa Jantung merupakan organ tubuh manusia yang mempunyai peran penting dalam kehidupan manusia dan pastinya sangat berbahaya jika jantung kita mempunyai masalah mengingat bahwa banyak kematian disebabkan oleh penyakit jantung. Tapi dengan pengetahuan dan informasi yang minim, mustahil untuk dapat menjaga kesehatan jantung. Oleh karena itu dibutuhkan seorang pakar yang ahli tentang jantung.

Tabel 2. Jumlah penggunaan internet di Kabupaten Bondowoso

\begin{tabular}{ll}
\hline Tahun & Prosentase \\
\hline 2010 & $6,94 \%$ \\
2011 & $15 \%$ \\
2012 & $20 \%$ \\
\hline
\end{tabular}

Sumber: Badan Pusat Statistik (BPS)

Kabupaten Bondowoso tahun 2012

Penelitian yang akan saya lakukan Aplikasi penentu faktor risiko untuk penyakit diabetes digunakan masyarakat yang belum terdiagnosa penyakit DM tipe 2 masyarakat dapat mengetahui secara dini terkait risiko penyakit ini. Berdasarkan tabel 1.2 renacana ini didukung oleh jumlah pengguna internet di Kabupaten Bondowoso yang bertambah. Pihak dinas kesehatan juga akan memberikan pengumuman terhadap adanya aplikasi ini melalui media radio dan pamvlet. Aplikasi ini dapat dimanfaatkan sebagai upaya preventif bagi Dinas Kesehatan Kabupaten Bondowoso dalam rangka mengurangi prevalensi DM di Kabupaten Bondowoso. Merancang Suatu Aplikasi Penentu faktor Risiko Penyakit Diabetes Melitus Tipe 2 Secara Dini Berbasis Web Di Kabupaten Bondowoso.

\section{Metodologi penelitian}

Jenis penelitian ini adalah menggunakan penelitian kualitatif berupa Pembuatan Aplikasi Penentu Faktor Risiko Penyakit Diabetes Melitus Tipe 2 Secara Dini Berbasis Web Di Kabupaten Bondowoso. Penelitian ini menggunakan perancangan pemrograman terstruktur dengan metode pengembangan waterfall atau air terjun. Dengan bahasa perograman $P H P$ dan database MySQL.

\section{Hasil dan pembahasan}

\subsection{Analisis Kebutuhan}

Pada tahapan ini langkah awal dan dasar yang harus dilakukan yakni lebih mempelajari dan menganalisis aplikasi yang akan berjalan melalui tahapan observasi, wawancara dan brainstorming. Kebutuhan yang sistem butuhkan diantaranya adalah faktor risiko dan gejala terhadap penyakit DM tipe 2. Ada beberapa faktor resiko penyakit DM tipe 2 yang harus mendapatkan perhatian serius untuk bisa terhindar dari penyakit yang bisa dibilang sangat mematikan ini. Keberadaan beberapa faktor risiko diabetes ini 
, akan menjadikan Anda memiliki peluang yang sangat besar untuk Anda terserang penyakit yang dikenal penyakit Kencing Manis. Oleh sebab itu peneliti tertarik untuk merancang aplikasi untuk menentukan secara dini faktor risiko penyakit DM tipe 2.

\subsection{Desain}

Tahapan berupa penggambaran, perencanaan dan pembuatan dengan menyatukan beberapa elemen terpisah ke dalam satu kesatuan yang utuh untuk memperjelas bentuk sebuah sistem. Mendesain suatu sistem dapat mempermudah dalam proses pembuatan sistem.

Desain yang digunakan dalam membuat aplikasi penentu faktor risiko penyakit diabetes melitus tipe 2 adalah Flowchart, context diagram, Data Flow Diagram, Entity Relationship Diagram.

Tabel keputusan adalah sebuah tabel yang akan dibuat acuan dalam membuat pohon keputusan, dalam tabel keputusan untuk menentukan apakah orang tersebut berisiko atau tidak menggunakan rumus proporsi sistem pakar penyakit, adapun rumusnya :

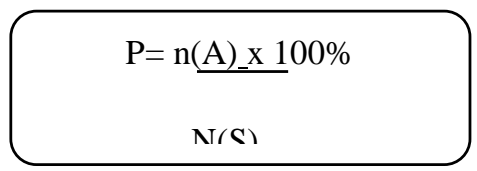

Gambar 4.6 Rumus Proporsi

Sumber : Dwi Tya, "sistem pakar untuk mendiagnosa penyakit anak(2008)",

Keterangan :

$\mathrm{P}=$ nilai proporsi

$\mathrm{n}(\mathrm{A})=$ banyaknya gejala yang terpenuhi pada penyakit $\mathrm{A}$

$n(S)=j u m l a h$ keseluruhan gejala penyakit A

Setelah diketahui nilai proporsi dari penyakit Diabetes melitus ini maka akan ditentukan status dengan aturan sebagai berikut:

1. Nilai proporsi antara $100 \%-75 \%$ maka hasil statusnya adalah "berisiko".
2. Untuk nilai proporsi $<75 \%$ maka hasil statusnya adalah "kemungkinan berisiko".

3. Dengan nilai proporsi $0 \%$ maka menunjukkan status "tidak berisiko".

\subsection{Pengkodean}

Pada tahap ini penerjemahan desain yang telah dilakukan sebelumnya menggunakan bahasa pemrograman PHP. Serta digunakan database MySQL..

\subsection{Pengujian}

Setelah sistem di didesain dan dirancang maka tahap selanjutnya dilakukan integrasi antar bagian menjadi satu kesatuan untuk selanjutnya dilakukan uji coba atau testing. Uji ini dilakukan sebagai uji fungsional dan agar error dalam sistem dapat diketahui menggunakan black box.

\section{Kesimpulan}

Berdasarkan hasil analisis kebutuhan untuk perangkat lunak aplikasi penentu faktor risiko penyakit diabetes melitus tipe 2 secara dini berbasis web di Kabupaten Bondowoso dilakukan pengumpulan kebutuhan dengan cara melakukan wawancara dan brainstorming kepada informan yang meliputi halaman admin dan user. Desain yang digunakan dalam membuat aplikasi penentu faktor risiko penyakit diabetes melitus tipe 2 adalah Flowchart, context diagram, Data Flow Diagram, Entity Relationship Diagram. Bahasa yang digunakan untuk pengkodingan dalam pembuatan aplikasi penentu faktor risiko penyakit diabetes melitus tipe 2 adalah $P H P, H T M L$. Pengujian yang dilakukan di Dinas Kesehatan Kabupaten Bondowoso menggunakan teknik pengujian black box.

Diharapkan aplikasi ini dapat digunakan di Dinas Kesehatan Kabupaten Bondowoso. Penderita diabetes melitus tipe 2 di Kabupaten Bondowoso diharapkan menurun untuk tahun selanjutnya. Aplikasi ini berbasis web browser peneliti selanjutnya dapat mengembangkan lagi berbasis android, atau iphone. Peneliti selanjutnya dapat ditambahkan konsultasi online dengan dokter.

\section{Daftar pustaka}

Abdul, Kadir. 2009. Membuat Aplikasi Web Dengan PHP Dan Database MySQL. Yogyakarta: ANDI OFFSET. 
Damayanti, Santi. 2015. Diabetes Melitus Dengan Pelaksanaan Keperawatan. 1st ed. Yogyakarta: Nuha Medika.

Dinas Kesehatan Republik Indonesia. 2013. "Riset Kesehatan Dasar 2013." Riset Kesahatan Dasar: 111-16.

Dinkes Jatim. 2013. "Profil Kesehatan Provinsi Jawa Timur Tahun 2012." : 3840.

Ditjen PP \& PL. 2008. "Petunjuk Teknis Pengukuran Faktor Risiko Diabetes Melitus." : 54. https://agus34drajat.files. wordpress.co m/2010/10/petunjuk-teknispengukuran-faktor-resiko-diabetesmilitus_2008.pdf.

Fathayansyah. 2012. Basis Data. Bandung: Informatika Bnadung.

Jeratnam dan Koh. 2009. Praktik Kedokteran Kerja. Jakarta: EGC.

Jogiyanto,Hartono. 1999. Analisis Dan Desain. Yogyakarta: ANDI OFFSET.

Kementrian Kesehatan RI. 2014. "Pusat Data Dan Informasi Kementrian Kesehatan RI 2014." : 2.

Kristanto, Hariyanto. 2010. Konsep \& Perancangan Database. Yogyakarta: ANDI OFFSET.

Kusrini. 2006. Sistem Pakar, Teori \& Aplikasi. 2nd ed. Yogyakarta: ANDI OFFSET.

Pressman, Roger. 2002. Rekayasa Perangkat Lunak. 1st ed. Yogyakarta: ANDI OFFSET.

Shalahudin, Rossa A.S \&. 2013. Rekayasa Perangkat Lunak Terstruktur Dan Berorientasi Pada Objek. Bandung: Informatika bandung.

.Sidik, Betha, Husni. 2012. Pemrograman Web Dengan HTML. Bandung: Informatika Bnadung.

Wangi, pandan. 2015. Sistem Pakar Screening Tuberkulosis Berbasis Web Terkait Peringatan Dini Dan Petugas Di Rumah
Sakit Paru Jember. Jember: Politeknik Negeri Jember.

WHO. 1999. "Definisi,diagnosis Dan Klasifikasi Diabetes. 